Vol. 10, Issue 20, pp. 212-218, 2021

https://doi.org/10.47068/ctns.2021.v10i20.029

\title{
RESEARCH ON RADON $\left({ }^{222}\right.$ Rn) CONTENT IN DRINKING-WATER SAMPLES COLLECTED FROM SIBIU COUNTY
}

\author{
Cecilia Ionela Tăban ${ }^{1 *}$, Simona Oancea ${ }^{2}$ \\ ${ }^{1}$ Public Health Directorate of Sibiu, 3 Gh. Baritiu Street, 550178 Sibiu, Romania \\ "Lucian Blaga" University of Sibiu, 7-9 I. Ratiu street, 550012 Sibiu, Romania \\ ${ }^{2}$ Faculty of Agricultural Sciences, Food Industry and Environmental Protection, \\ "Lucian Blaga" University of Sibiu, 7-9 I. Ratiu street, 550012 Sibiu, Romania
}

\begin{abstract}
The isotope radon $\left({ }^{222} \mathrm{Rn}\right)$, an inert water-soluble gas that may contaminate water, represents a potential risk for human health, including cancer. The present study reports the evaluation of the ${ }^{222} \mathrm{Rn}$ concentration in drinking-water samples collected in 2020 from 10 sources located in Sibiu County, as measured using the pulse ionization chamber. Values of ${ }^{222}$ Rn varied from 0.0549 to $37.4770 \mathrm{~Bq} / \mathrm{l}$, with an average of $4.586 \mathrm{~Bq} / \mathrm{l}$. These values were below the maximum level of $100 \mathrm{~Bq} / \mathrm{l}$ recommended by WHO and EU Directive/Euratom. With the exception of the sample from groundwater, the others showed ${ }^{222} \mathrm{Rn}$ values below the maximum level of $11.1 \mathrm{~Bq} / \mathrm{l}$, as recommended by US EPA. In the case of impermeable soils, this radionuclide floats inside the cracks until it reaches the atmospheric air, so it is harmful to human health both in water and in the air. Evaluation of radon in water, in particular from groundwater sources becomes essential for the management of remedial solutions.
\end{abstract}

Keywords: drinking-water, pulse ionization detector, radon.

\section{INTRODUCTION}

Several radionuclides and their decay products have been of environmental concern, as such pollutants generated from natural or anthropogenic sources may contaminate water (Qin-Hong et al., 2010). Among radionuclides, radon, ${ }^{222} \mathrm{Rn}$, represents a radioactive gas originating from the disintegration of radium, the latter being the decay product of uranium, ${ }^{238} \mathrm{U}$. The half-life of ${ }^{222} \mathrm{Rn}$ is 3.82 days (Alirezazadeh et al., 2005).This element has been identified as the main source of natural radioactivity with short-term products of ${ }^{238} \mathrm{U}$ disintegration, including ${ }^{214} \mathrm{Po},{ }^{218} \mathrm{Po},{ }^{214} \mathrm{Bi}$ and ${ }^{214} \mathrm{~Pb}$ (Alirezazadeh et al., 2005; Sathish et al., 2009; Richon et al., 2010; Binesh et al., 2012). Research studies reported evidence of carcinogenicity of the ${ }^{222} \mathrm{Rn}$ radioactive gas (Rafique et al., 2012), being responsible of the internal exposure in humans, according to the report of the International Commission on Radiation Protection (ICRP) (Negarestani et al., 2011). The effect of the inhaled radon on human health is lung 
Vol. 10, Issue 20, pp. 212-218, 2021

https://doi.org/10.47068/ctns.2021.v10i20.029

Current Trends in Natural Sciences (on-line)

ISSN: 2284-953X

Current Trends in Natural Sciences (CD-Rom)

ISSN: 2284-9521

ISSN-L: 2284-9521

ISSN-L: 2284-9521

cancer, while that of the ingested radon through the digestive tract is gastric cancer (Alirezazadeh et al., 2005; Binesh et al., 2012; Rafique et al., 2012).

Radon is a dangerous gas contaminating soil, rocks and water, sources which may become a risk for human health. Of great concern is the presence of ${ }^{22} \mathrm{Rn}$ in water, which conducted to an increase of studies directed toward the evaluation of its level in different water sources, over the past two decades (Abdallah et al., 2007). The current methods applied for ${ }^{222} \mathrm{Rn}$ analysis include several techniques, based on (a) the gamma ray spectrometry (the so-called radiometric method); (b) the emanometry methodology; (c) liquid scintillation counting (LSC analysis) (ASRO-2020).

The aim of the present paper was to investigate the radon concentration in water sampled from different areas of the Sibiu County, Romania, in order to identify the nature of potential exposure to radon from water intended for human consumption, originating in different types of water sources, both from the surface and from the underground.

\section{MATERIALS AND METHODS}

\section{Sampling procedure}

A number of 10 water samples were collected, starting on February and ending on November 2020, from water supplies, as follows: Sibiu (98\% surface water and 2\% groundwater, originating from the Cibin river), Alma, Avrig (surface water originating the Avrig river), Dumbrăveni, Mediaș (surface water originating the Târnava Mare river), Cisnădie and Sadu (surface water originating the Sadu river), Păltiniş (water from captured/ mixed springs), Săcel and Sibiel (water from ground wells), all zones being located in the Sibiu county.

Samples were collected in glass vessels and sealed until analysis. The maximum shelf life of samples collected in a glass container is one day, as recommended by SR ISO 5667-3. An aliquot of water was injected into the degassing vessel. Analysis was done immediately after removing the plug in order to minimize the escape of radon from the sample into the surrounding air.

\section{Quantification of radon, ${ }^{222} \mathrm{Rn}$}

The AlphaGuard type DF 2000 system and the AquaKIT were used. Before the sample measurement, a cycle of measuring the existing air was allowed in the installation, with all the containers and tubes connected. The predefined measurement cycles into the device are of 1 minute and 10 minutes, respectively. The same kind of cycle was used, as for measuring the sample. The radon background in the empty installation was measured, followed by the sample measurement. The determination of radon concentration in water samples is based on the indication of the radon monitor. This measurement value is not yet the radon concentration in the measured sample, because the removed radon has been diluted. To quantify the dilution effect, the exact internal volume in the measurement setting (Vsystem) was determined. The amount of radon remaining in the sample was determined by using the distribution coefficient k, as shown in Figure 1.

The diffusion coefficient $\mathrm{k}$ indicates the radon concentration ratio in aqueous phase and the existing air volume, which is temperature-dependent. As temperature drops down, the amount of water-soluble radon increases. The diffusion coefficient $\mathrm{k}$ increases as the temperature decreases. The influence of the radon diffusion coefficient $\mathrm{k}$ is low in the temperature range $10-30^{\circ} \mathrm{C}$. This is suitable as long as the samples are measured under normal conditions and leads to an uncertainty of less than $2 \%$, being 
Current Trends in Natural Sciences

Vol. 10, Issue 20, pp. 212-218, 2021

https://doi.org/10.47068/ctns.2021.v10i20.029

Current Trends in Natural Sciences (on-line)

therefore negligible for the error resulting from the sample processing. Temperature deviations of $\pm 10^{\circ}$ $\mathrm{C}$ would result in a measurement error of up to $7 \%$ if this factor is not used.

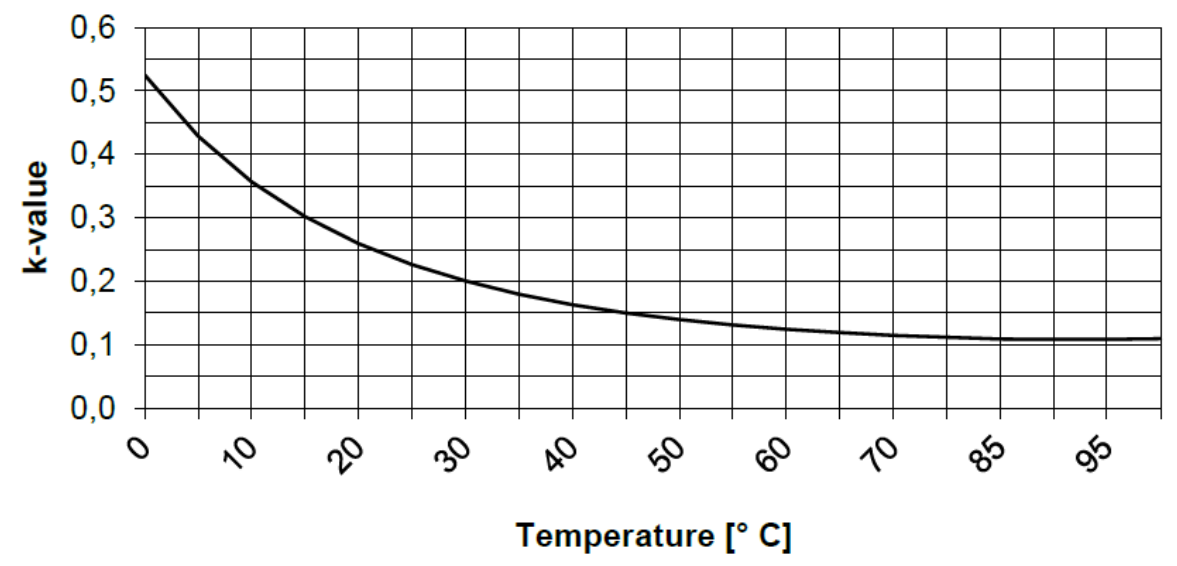

Figure 1. The temperature dependence of the diffusion coefficient $k$, for the water / air phase transition follows:

The equation for the calculation of the radon concentration in the measured water sample is as

$$
C_{\text {water }}=\frac{C_{\text {air }} x\left(\frac{V_{\text {system }}-V_{\text {sample }}}{V_{\text {sample }}}+k\right)-C_{0} x\left(\frac{V_{\text {system }}-V_{\text {sample }}}{V_{\text {sample }}}\right)}{1000}
$$

where

$\mathrm{C}_{\text {water }}=$ radon concentration in water $(\mathrm{Bq} / \mathrm{l})$

$\mathrm{C}_{\mathrm{air}}=$ radon concentration in the air resulting from sparging water $(\mathrm{Bq} / \mathrm{l})$

$\mathrm{C}_{0}=$ background radon concentration $(\mathrm{Bq} / \mathrm{l})$

$\mathrm{V}_{\text {system }}=$ internal volume of the measuring facility $(\mathrm{ml})$

$\mathrm{V}_{\text {sample }}=$ volume of the analyzed sample $(\mathrm{ml})$

$\mathrm{k}=$ diffusion coefficient

The results of ${ }^{222} \mathrm{Rn}$ concentration $\left(\mathbf{C}_{\mathbf{R n}}\right)$ are expressed in Becquerels per liter $(\mathrm{Bq} / \mathrm{l})$.

\section{RESULTS AND DISCUSSIONS}

The present study reports the evaluation of the concentration of ${ }^{222} \mathrm{Rn}$ in 10 samples of drinking-water collected during the months of February-November 2020 from different regional points of Sibiu County, Romania.

The results are presented in Table 1 .

The lowest ${ }^{222} \mathrm{Rn}$ concentration $(0.0549 \mathrm{~Bq} / \mathrm{l})$ was registered in the surface drinking-water collected from the Cisnădie city, while the highest one $(37.4770 \mathrm{~Bq} / \mathrm{l})$ was recorded in the drinking-water sample from Păltiniș, which is a mountain resort situated at $1440 \mathrm{~m}$ at $32 \mathrm{~km}$ North of the Sibiu city. The Păltiniș water sample originated from the captured (mixed) springs, transported through supply pipes so 
Current Trends in Natural Sciences

Vol. 10, Issue 20, pp. 212-218, 2021

https://doi.org/10.47068/ctns.2021.v10i20.029

Current Trends in Natural Sciences (on-line) ISSN: 2284-953X

ISSN-L: 2284-9521
Current Trends in Natural Sciences (CD-Rom) ISSN: 2284-9521 ISSN-L: 2284-9521

that it could then be filtered and disinfected. The groundwater in the mountainous region belongs mostly to the subregion corresponding to the crystalline schists. In the foothill region, significant quantities of groundwater are confined to greater depths in the piedmont deposits. Deep waters are present in the foothill region, where friable sedimentary deposits prevail (Raport de mediu, 2015). The sample of Păltiniș water was collected in November 2020 from the Cindrel Hotel network. The investigated level of the Păltiniș sample showed higher values than the other samples also due to the fact that it is a groundwater.

Table 1. Radon, ${ }^{222} \mathrm{Rn}$, concentration in drinking-water samples collected from different sources of the Sibiu County, Romania (mean values \pm standard deviation)

\begin{tabular}{|l|l|l|}
\hline $\begin{array}{c}\text { Sample } \\
\text { no. }\end{array}$ & Location & \multicolumn{1}{|c|}{$\begin{array}{c}\text { Radon } \\
(\mathbf{B q} / \mathbf{l})\end{array}$} \\
\hline 1 & Sibiu & $0.1410 \pm 0.0221$ \\
\hline 2 & Alma & $0.4251 \pm 0.0547$ \\
\hline 3 & Avrig & $0.0890 \pm 0.0152$ \\
\hline 4 & Dumbrăveni & $1.1831 \pm 0.1385$ \\
\hline 5 & Mediaș & $0.1295 \pm 0.0201$ \\
\hline 6 & Păltiniş & $37.4770 \pm 2.5767$ \\
\hline 7 & Săcel & $3.9644 \pm 0.4076$ \\
\hline 8 & Sibiel & $2.3131 \pm 0.2168$ \\
\hline 9 & Cisnădie & $0.0549 \pm 0.0070$ \\
\hline 10 & Sadu & $0.0923 \pm 0.0175$ \\
\hline
\end{tabular}

The frequency distribution of ${ }^{222} \mathrm{Rn}$ concentration in drinking-water collected from the 10 areas of the Sibiu County is presented in Figure 2. The mean value of ${ }^{222} \mathrm{Rn}$ concentration in drinking-water within Sibiu County for the year 2020 was found to be $4.5860 \mathrm{~Bq} / \mathrm{l}$.

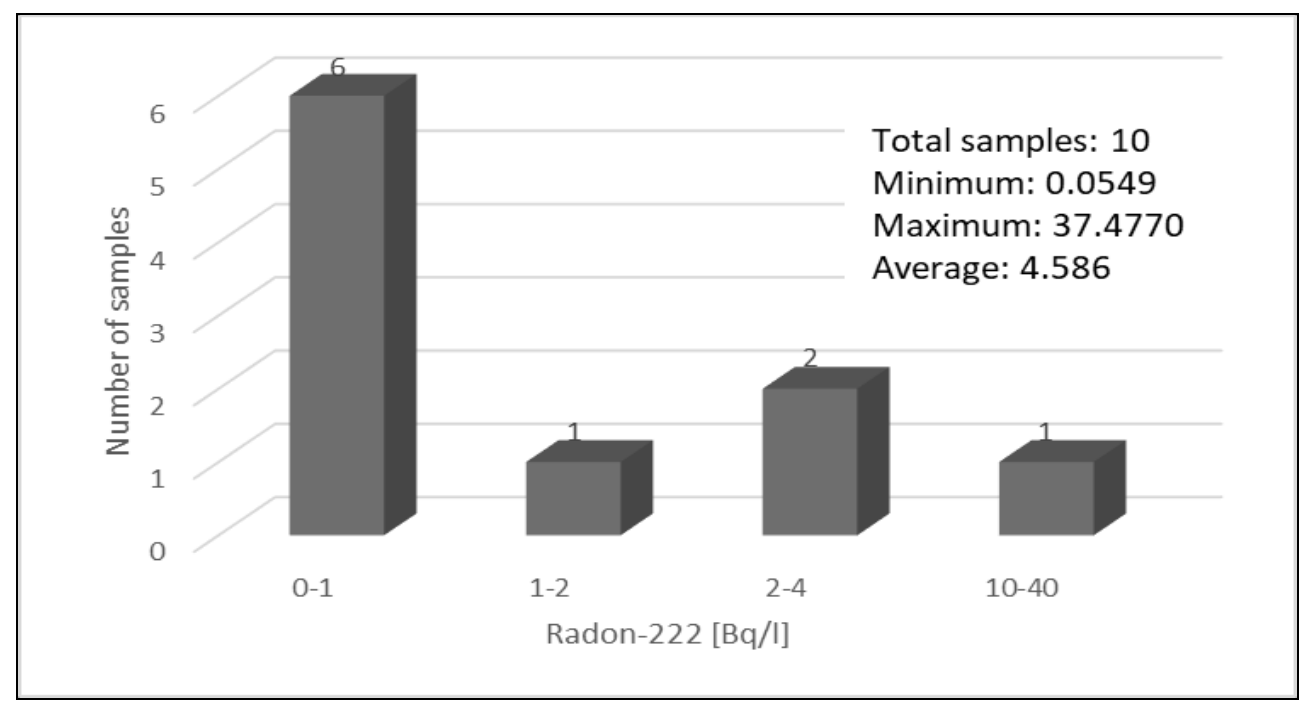


Figure 2. Frequency distribution of ${ }^{222} \mathrm{Rn}$ concentration in drinking-water in the Sibiu County

The EU Council Directive 2013/51/Euratom laying down requirements for the protection of the public health with regard to radioactive substances in water intended for human consumption set the parametric value of water for human consumption at $100 \mathrm{~Bq} / \mathrm{l}$ (Council Directive, 2013). The WHO recommendation for maximum level of ${ }^{222} \mathrm{Rn}$ in drinking-water is $100 \mathrm{~Bq} / \mathrm{l}$ (WHO, 2008) as well, while the US EPA established the maximum level at $11.1 \mathrm{~Bq} / 1$.

There are national standards regarding the water quality with respect to ${ }^{222} \mathrm{Rn}$, as follows: (a) ISO 13164-2:2020 Water quality ${ }^{222} \mathrm{Rn}$ Part.2. Test method using gamma-ray spectrometry; (b) ISO 131643:2020 Water quality ${ }^{222} \mathrm{Rn}$ Part.1-3. Test method using emanometry, and (c) ISO 13164-4:2020 Water quality ${ }^{222} \mathrm{Rn}$. Test method two - phase liquid scintillation counting (ASRO, 2020).

Table 2. Reported values of radon concentration in water samples collected from different world regions.

\begin{tabular}{|l|l|l|l|}
\hline \multicolumn{1}{|c|}{$\begin{array}{c}\text { Type of water } \\
\text { sample }\end{array}$} & \multicolumn{1}{|c|}{$\begin{array}{c}\text { 222 Rn } \\
(\mathbf{B q} / \mathbf{l})\end{array}$} & \multicolumn{1}{c|}{ Region, country } & \multicolumn{1}{c|}{ Ref. } \\
\hline Drinking water & $3.176-49.932$ & $\begin{array}{l}\text { Shanono and Bagwai, } \\
\text { Nigeria }\end{array}$ & Bello et al., 2020 \\
\hline Drinking water & $<3$ & Novi Sad /Serbia & Todorovic et al., 2012 \\
\hline Surface water & $<1$ & Slovenia & ISO 13164-3, 2013 \\
\hline Groundwaters & $1-1000$ & La Garrotxa, Spain & ISO 13164-3, 2013 \\
\hline Groundwaters & 3043 & Mountains Sudety, Poland & Przylibski et al., 2014 \\
\hline Groundwaters & $17-3856$ & Nisa, Portugal & Pereira et al., 2015 \\
\hline $\begin{array}{l}\text { Unbottled mineral } \\
\text { spring waters }\end{array}$ & $1.4-105$ & South Catalonia, Spain & Fonollosa et al., 2016 \\
\hline $\begin{array}{l}\text { Unbottled mineral } \\
\text { spring waters }\end{array}$ & $1.5-181$ & $\begin{array}{l}\text { Euganean } \\
\text { District, Padua, Italy }\end{array}$ & Cantaluppi et al., 2014 \\
\hline Fountain water & $10-300$ & Norway & ISO 13164-3, 2013 \\
\hline Fountain water & $4-63560$ & Stockholm, Sweden & Skeppstrom et al., 2006 \\
\hline Drinking water & $2.96 \pm 0.966$ & West Region of Iran & Pirsaheb et al., 2015 \\
\hline Drinking water & $0.87-0.384$ & Bandar Abbas City, Iran & Fakhri and Oliveri et al., 2016 \\
\hline Tap water & $0.46 \pm 0.04$ & Minab City, Iran & Fakhri and Kargosha et al., 2016 \\
\hline Bottled water & $\begin{array}{l}0-901 \\
\left(\mathrm{~Bq} / \mathrm{m}^{3}\right)\end{array}$ & Bandar Abbas City, Iran & Fakhri and Hossein et al., 2016 \\
\hline Groundwaters & $0.168-78.509$ & Ijero, Ekiti State, Nigeria & Akinnagbe et al., 2018 \\
\hline Groundwaters & $7.41 \pm 2.04$ & Zaria, Nigeria & Garba et al., 2012 \\
\hline Groundwater & $7.002 \pm 0.33$ & Kaduna State, Nigeria & Kamba et al., 2016 \\
\hline
\end{tabular}

According to the maximum levels admitted for water for human consumption, samples of drinkingwater from Sibiu County showed values below those reported by the EU and WHO regulations. With regard to the US EPA recommendations, only the sample from Păltiniss mountain-resort exceeded the established values, while the others can be considered appropriate with values well below the 
Vol. 10, Issue 20, pp. 212-218, 2021

https://doi.org/10.47068/ctns.2021.v10i20.029

Current Trends in Natural Sciences (on-line)

ISSN: 2284-953X

Current Trends in Natural Sciences (CD-Rom)

ISSN: 2284-9521

ISSN-L: 2284-9521

ISSN-L: 2284-9521

maximum admitted level. Studies have shown that radon concentration may decrease during processing, transport or storage of water (Gruber et al., 2009). However, evaluation of the radon concentration in different sources of water, in particular in groundwater, becomes essential for the potential detection of radon in drinking-water. In such cases, measurements for the reduction of radon concentration are required, as inhalation or ingestion of radon become harmful for human health.

Table 2 indicates several values of ${ }^{222} \mathrm{Rn}$ concentration in water samples collected from different world regions.

\section{CONCLUSIONS}

The average concentration of radon, ${ }^{222} \mathrm{Rn}$, determined in 10 water samples collected from different areas of the Sibiu County, in 2020, was $4.586 \mathrm{~Bq} / \mathrm{l}$, value which did not exceed the maximum level set by EPA and WHO regulations. Out of the total 10 samples, 6 samples were surface waters, and the rest were groundwaters and wells. The minimum value $(0.0549 \mathrm{~Bq} / \mathrm{l})$ was found in the Cisnădie water sample, which is surface water. The water samples collected from Dumbrăveni, Săcel and Sibiel (groundwaters, from wells) contain radon in concentration of $1.1831 \mathrm{~Bq} / 1,3.9644 \mathrm{~Bq} / \mathrm{l}$, and 2.3131 $\mathrm{Bq} / 1$, respectively, being slightly higher than that of Cisnădie sample, but within the allowed limits. The maximum value of ${ }^{222} \mathrm{Rn}(37.4770 \mathrm{~Bq} / \mathrm{l})$ was found in the groundwater sample from Păltiniș area, concentration that exceeds the EPA allowed limits, but were within the WHO guideline set at $100 \mathrm{~Bq} / \mathrm{l}$.

The recommendation is to use water storage tanks for aeration and radon removal from water samples showing high concentration of radon, in order to reduce the consequences of exposure to this radioactive gas. Water sources high in radon should be avoided for household use.

\section{REFERENCES}

Abdallah, S.M., Habib, R.R., Nuwayhid,R.Y., Chatila, M., Katul, G. (2007). Radon measurements in well and spring water in Lebanon. Radia_on measurements, 42, 298-303.

Alirezazadeh, N. (2005) Radon concentrations in public water supplies in Tehran and evaluation of radiation dose. Iran J Radiat Res, 3, 79-83.

Akinnagbe, D.M., Orosun, M.M., Orosun, R.O., Osanyinlusi, O., Yusuk, K.A., Akinyose, F.C., Olaniyan, T.A., Ige,S.O. (2018). Assessment of Radon concentration of ground water in Ijero Ekiti, Manila J. Sci. 11, 32-41.

ASRO, Buletinul Standardizarii. Publicatia oficiala a Organismului National de Standardizare - martie 2020.

Bello, S., Nasiru, R., Garba, N.N., .Adeyemo, D.J. (2020). Annual effective dose associated with radon, gross alpha and gross beta radioactivity in drinking water from gold mining areas of Shanono and Bagwai, Kanostate, Nigeria, Microchemical Journal 154, 104551.

Binesh, A., Mowlavi, A., Mohammadi, S. (2012). Estimation of the effective dose from radon ingestion and inhalation in drinking water sources of Mashhad, Iran. Int J Radiat Res, 10, 37-41.

Cantaluppi, C., Fasson, A., Ceccotto, F., Cianchi, A., Degetto, S. (2014). Radionuclides concentration in water and mud of euganean thermal district, Int. J. Environ. Res. 8, 237-248.

Council Directive, 2013/51/ EURATOM of 22 October 2013, Official Journal of the European Union pag. L.296/16.

Fonollosa, E., Pe nalver, A., Borrull, F., Aguilar, C. (2016). Radon in spring waters in the south of Catalonia, J. Environ. Radioact. 151 275-281.

Fakhri, Y., Hossein, A.M., Langarizadeh, G.., Zandsalimi, Y., Rasouli, L.A., Kargosha, M., Moradi, M., Moradi, B., Mirzaei, M. (2016). Effective dose of Radon 222 bottled water in different age groups humans: Bandar Abbas city, Iran, Glob. J. Health Sci. 8 (2), 64-71.

Fakhri, Y., Oliveri, G..C., Ferrante, M., Bay, A., Avazpour, M., Moradi, B., Zandsalimi, Y., Rasouli, L.A., Langarizadeh, G., Keramati, H. (2016). Assessment of concentration of Radon 222 and effective dose; Bandar Abbas city (Iran)

http://www.natsci.upit.ro

*Corresponding author, E-mail address: tceciliaionela@yahoo.com 


\section{Current Trends in Natural Sciences}

Vol. 10, Issue 20, pp. 212-218, 2021

https://doi.org/10.47068/ctns.2021.v10i20.029

Current Trends in Natural Sciences (on-line)

ISSN: 2284-953X

ISSN-L: 2284-9521
Current Trends in Natural Sciences (CD-Rom)

ISSN: 2284-9521

ISSN-L: 2284-9521

citizens exposed through drinking tap water, Int. J. Pharm Techn. 8 (1), 10782-10793.

Fakhri, Y., Kargosha, M., Langarizadeh, G.., Zandsalimi, Y., Rasouli, L.A., Moradi, M., Moradi, B., Mirzaei, M. (2016). Effective dose Radon 222 of the tap water in children and adult people; Minab city, Iran, Glob. J. Health Sci. 8 (4), 234-243.

Garba, N.N., Rabi'u, N., Dewu B.B.M. (2012). Preliminary studies on 222Rn concentration in ground water from Zaria, Nigeria, J. Phys. Sci. 23 (1), 57-64.

Gruber, N., Gloor, M., Sara, E., Fletcher, M., Scott, C. (2009). Doney et al., Oceanic Sources,sinks and transport of atmospheric $\mathrm{O} \square$ Global Biogeochemical Cycles/ Volum23, Issue 1.

ISO 13164-3, Water Quality - Radon-222- Part 1-3, International Organization for Standardization, Geneva, 2013.

Kamba, A.M., Okunade, I.O. (2016). Radon measurement in commercial borehole water from some selected areas of Kaduna metropolis using liquid scintillation counting, Int. J. Math. Phys. Sci. Res. 3 (2), 71-81.

Negarestani, A., Hashemi, S., (2011) Effective dose rates from radon hot springs boiling in Kerman province. Journal of Kerman University of Medical Sciences, 18(3), 279-285.

Raport de mediu pentru Planul de amenajare a teritoriului zonal intercomunal Paltinis-Cindrel (Environmental Report, Paltinis-Cindrel Intercommunal Zonal Teritorritorial Development Plan), Centrul de cercetari pentru Managementul dezastrelor, pp. 31, 2015. https://www.cjsibiu.ro/wp-content/uploads/2015/01/raport-mediu-PATZIC-PaltinisCindrel-26-IAN-2015.pdf

Pereira, A.J.S.C., Pereira, M.D., Neves, L.J.P.F., Azevedo, J.M.M., Campos, A.B.A. (2015). Evaluation of groundwater quality based on radiological and hydrochemical data from two uraniferous regions of western Iberia: Nisa (Portugal) and Ciudad Rodrigo (Spain), Environ. Earth Sci. 73, 2717-2731.

Pirsaheb, M., Sharafi, M., Hemati, L., Fazlzadehdavil, M. (2015). Radon measurement in drinking water and assessment of average annual effective dose in the west region of Iran, Fresenius Environ. Bull. 24 (10B), 3515-3519.

Przylibski, T.A., Gorecka, J., Kula, A., Fijałkowska-Lichwa, L., Zagozdzon, K.., Zagozdzon, P., Mitista, W., Nowakowski, R. (2014). 222Rn and 226Ra activity concentrations in groundwaters of southern Poland: new data and selected genetic relations, J. Radioanal. Nucl. Chem. 301, 757-764.

Qin-Hong H., Weng, J.-Q., Wang, J.-S. (2010). Sources of anthropogenic radionuclides in the environment: a review, Journal of Environmental Radioactivity, 101 (6), 426-437.

Rafique, M., Manzoor, N., Rahman, S., Rahman, S., Rajput, M., (2012) Assessment of lung cancer risk due to indoor radon exposure in inhabitants of the state of Azad Kashmir; Pakistan. Int J Radiat Res, 10, 19-29.

Richon, P., Klinger, Y., Tapponnier, P., Li C-X, Van Der Woerd J, Perrier, F. (2010) Measuring radon flux across active faults: Relevance of excavating and possibility of satellite discharges. Radiation Measurements, 45, 211-218.

Sathish, L., Nagaraja, K., Ramanna, H., Nagesh, V., Sundareshan, S. (2009) Concentration of radon, thoron and their progeny levels in different types of floorings, walls, rooms and building materials. Int J Radiat Res, 7, 1-9.

Skeppstrom, K., Olofsson, B. (2006). A prediction method for Radon in groundwater using GIS and multivariate statistics, Sci. Total Environ. 367, 666-80.

Todorovic, N., Nikolov, J., Forkapic, S., Bikit, I., Mrdja, D., Krmar, M., Veskovic, M. (2012). Public exposure to radon in drinking water in Serbia, Appl. Radiat. Isot. 70, 543-549.

World Health Organization WHO Geneva 2008, Guidelines for Drinking-water Quality, Third Edition Incorporating the first and second Addenda Vol.1, Guidance on radon in drinking- water supplies 9.5.3, pag. 207. 